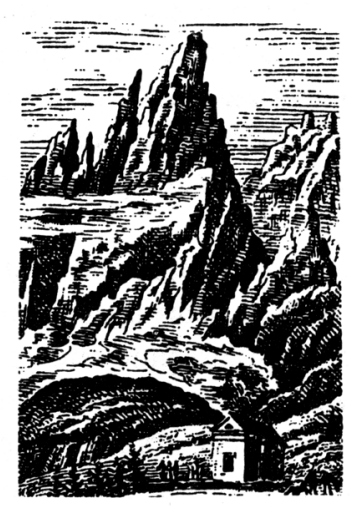

Aleksandra Kmak-Pamirska

Niemiecki Instytut Historyczny w Warszawie

pamirska@dhi.waw.pl

DOI: 10.19195/2084-4107.10.7

\title{
Góry: Zamkowa, Królowej Bony, Grabarka — symbolika „mniej znanych gór" w świadomości kulturowej w regionach wschodniej Polski na przełomie XIX i XX wieku
}

Słowa-klucze: góra, literatura wspomnieniowa, Kresy, pogranicze kultur

Regiony wschodniej Polski to tereny zróżnicowane kulturowo, etnicznie i religijnie. Przez wieki krzyżowały się tam odmienne wpływy oraz tradycje narodowe i kulturowe, w związku z czym powstał wielobarwny konglomerat. Mozaika narodowościowo-kulturowo-religijna łącząca w sobie elementy tradycji polskiej, (biało) ruskiej, ukraińskiej, tatarskiej i żydowskiej, sięgająca do korzeni takich religii, jak: islam, prawosławie, katolicyzm i judaizm, konstytuuje wyobrażenie przeszłości i wpływa na kształt świadomości kulturowej mieszkańców owych regionów.

Analizując literaturę, podania ludowe, pieśni i świadectwa kulturowe, można stwierdzić, że w świadomości społecznej mieszkańców terenów Polski wschodniej w ostatnich dekadach XIX i w pierwszych dziesięcioleciach XX w. góry stały 
się jednym z motywów symbolicznych. Oczywiście Tatry, Karpaty, Sudety odgrywały większą rolę niż „mniej znane góry”, znajdujące się w regionach Polski wschodniej, jednakże ciekawe jest odszukanie świadectw kulturowych i literackich traktujących właśnie o „górach mniej znanych”, takich jak Góra Zamkowa, Góra Królowej Bony czy Góra Grabarka. Ta ostatnia od lat 50. XX w. zyskała na znaczeniu, w związku z wybudowanym tam monasterem $\mathrm{i}$ jej historią odnoszącą się do cudownych uzdrowień.

Góry przez wieki postrzegano jako łącznik między światem sacrum i profanum. Góra poprzez swój kształt identyfikowana była z axis mundi, a jej wierzchołek z miejscem związanym ze światem wyższym, ze światem bóstw i niebem. Mircea Eliade w publikacji Sacrum i profanum ${ }^{1}$ stwierdzał, analizując kształtowanie świata „tu i teraz” przez społeczności tradycyjne odwzorowujące świat boski, tworząc świat ziemski, że: „łączność z niebem mogą wyrażać różne obrazy, wszystkie one w jakiś sposób odnoszą się jednak do axis mundi: kolumna (universalis columna), drabina (drabina Jakubowa), góra, drzewo, liana itd."” Góra, „będącą punktem styku nieba z ziemią, znajduje się w „centrum świata" i oczywiście jest najwyższym punktem na świecie"3, wiąże się z symboliką wstępowania - ruchu w górę i zstępowania — ruchu w dół. Jak wiadomo: „Wszystko, co bliższe jest niebu partycypuje w mniejszym lub większym stopniu w transcendencji”. Z Zatem, jak twierdzi Eliade: „Każde „wstępowanie” staje się przełamaniem danej płaszczyzny, przejściem na tamtą stronę, przekroczeniem świeckiej przestrzeni i sposobu bycia"5. Wstępowanie na górę wiąże się z przekraczaniem granicy świata profanum. Celem pielgrzymowania, samemu w sobie związanemu ze światem sacrum, często są miejsca święte ulokowane na górach bądź wzniesieniach, jak na przykład wspomniana Grabarka.

Wiersz Franciszka Łubieńskiego ilustruje powyższe słowa, ukazuje związek gór ze światem sacrum i wyjście poza obręb świata ziemskiego podczas wędrówki górskiej. W wierszu Przechadzka po górach Łubieński stwierdza:

O góry! gdy po waszych przechadzam się szczytach, Sercem jestem na ziemi, a myślą w błękitach! Lecz jak orzeł, chcąc ziemskie opuścić dziedziny, Nim piersi swoje wzbije w podniebne krainy, Strąciwszy się ze skały skrzydły zuchwałemi, Jeszcze raz tęskne koło w głąb zawodzi niemi: Tak jak ze szczytu góry, nim w nieba wyżyny Myślą strzelę - nie mogę nie westchnąć do ziemi! [Poezje, 1845$]^{6}$

\footnotetext{
${ }^{1}$ M. Eliade, Sacrum i profanum, Kraków 1999.

2 Ibidem, s. 29.

3 M. Eliade, Traktat o historii religii, Warszawa 1966, s. 102.

${ }^{4}$ Ibidem, s. 103.

5 Ibidem, s. 103.

${ }^{6}$ J. Kolbuszewski, Strofy o górach. Antologia, Warszawa 1981, s. 45.
} 
Niniejszy artykuł ma na celu odnalezienie symbolicznego znaczenia „mniej znanych gór" w świadomości kulturowej mieszkańców regionów wschodniej Polski, głównie w okresie przełomu XIX i XX w. Z Górą Zamkową wiązano wiele legend na przestrzeni wieków. Julian Borzym, szlachcic podlaski, wspominał w pamiętnikach opisując krajobraz Drohiczyna:

Rzeka Bug płynie pod Drochiczynem prosto z południa i uderza na środek miasta, spotykając góre zamkową, odbija się od niej, łamie się pod kątem prostym i płynie na zachód odcinając część miasta, a ponieważ rzeka Bug stanowi granicę, więc część odcięta jest już w Polsce, w tej części jest cerkiew i dlatego nazwa jej jest Drojczyn. Ruska strona, chociaż tu kalendarz już obowiązuje nowego stylu. Ta część miała swojego burmistrza.

O tej gorze zamkowej między mieszczanami przechowały się rozmaite podania. Opowiadano, że wewnątrz są ukryte skarby, to znowu, że to był zamek Księcia Jadźwingów, których Drochiczyn był stolicą, to znowu, że Królowa polska Bona w czasie głodu, aby dać ludziom zarobek kazała tę górę usypać, to znowu, że jeden z króli polskich koronował się w Drochiczynie i na pamiątkę kazał usypać. Ze strony wschodniej w połowie wysokości jest otwór do wewnątrz góry. Są ślady korytarza sklepionego, który prowadzi wewnątrz, lecz czas i woda zatarły i zamyły dalsze ślady. Woda z każdym rokiem podczas powodzi na wiosnę, znaczną część obrywa, do tego stopnia, ze zaczynają być widne lochi znajdujące się wewnątrz. Niektórzy badacze utrzymują, że to jest zwykła prochownia, być może, ale mnie się zdaje, że ta góra jest to sztuczna brama zabezpieczająca miasto od naporu wody, przytym może przechowywano w niej większą ilość prochów jako odpowiednio najbezpieczniejszym miejscu?

Górze Zamkowej przypisywano różne pochodzenie. Jedna z legend wiążąca się poniekąd z wypowiedzą Juliana Borzyma, mówiła, że: „,pod Górą Zamkową w złotym grobie pochowany jest ostatni z wodzów jaćwieskich - Komata"8. Kolejna legenda, w której również można odnaleźć odniesienie do poglądów podlaskiego szlachcica, głosiła, że raz na sto lat otwierają się wrota góry, celem wypuszczenia łodzi z rycerzami na wody Bugu. Wędrowali oni aż po świt. W odległych latach jeden z nich zapatrzył się na mieszczankę i nie wrócił do wnętrza

7 J. Borzym, Pamiętnik podlaskiego szlachcica, Łomża 2009, s. 62. Zapis cytatu zgodny z oryginałem tekstu, włącznie z błędami ortograficznymi m.in. w nazwie „Drochiczyn”, czy zapisie „przytym”. J. Belina Borzym urodził się w 1840 r. w Wierzbowiźnie, po sprzedaży majątku w Hruszewie zamieszkał wraz z żoną — Florentynną Marianną Belina Borzym h. Ślepowron z Obniskich w Warszawie. Został pochowany w Warszawie na Cmentarzu Powązkowskim. Dziadkowie i rodzice J. Borzyma: dziadek Ludwik Borzym, babcia Marynia z Dobrzyńskich. Ojciec Wincenty Borzym, matka Emilia z Pisarzewskich; J. Borzym, op. cit., s. 7-8.

${ }^{8}$ T. Lippoman, Legendy Podlasia, Białystok 2008, s. 161. W. hr. z Tęczyna Ossoliński, Wspomnienia z Podlasia. O uroczysku historycznem zwanem Kumat - tekst poświęcony historii śmierci ostatniego wodza Jadźwingów i miejscu jego pochówku. 
góry. Wrota zamknęły się przed jego przybyciem. Od tego momentu miał on się błąkać po nadbużańskich łąkach i oczekiwać ponownego otwarcia wrót. Rycerz był widywany w księżycowe noce na prawym brzegu rzeki ${ }^{9}$.

Legendy o Górze Zamkowej niejednokrotnie wiążą się z osobą Królowej Bony. Wzgórze, na którym znajdował się zamek, często nazywano Górą Zamkową. Lokowano wokół niego gród, co wiąże się z motywem fundacyjnym i narodowym. Jak podkreśla Gloger, historyk, archeolog, etnograf, językoznawca, badacz kultury polskiej w XIX i na początku XX w., w artykule pt. Liszków:

Liszków, a raczej Liszkowo, po litewsku Liszklawa, jest wioską w guberni suwalskiej, w okolicach Druskiennik i Merecza, z pięknym, daleko widocznym kościołem, wzniesionym na wysokiej nadniemeńskiej górze. Stromej i wyniosłej innej górze nad Niemnem zawdzięcza ta miejscowość swoje historyczne stanowisko w dziejach Litwy; takich bowiem miejsc, na dawne czasy warownych, poszukiwano do budowania zamków, które stawały się ogniskami życia prowincji, teatrem dziejowych wypadków i początkiem bardzo wielu miast. Kraków, Wilno, Lwów, Grodno, Płock i setka grodów lub wiosek innych wzniosły się u podnóża podobnych gór zamkowych ${ }^{10}$.

Z Górą Zamkową możemy się spotkać także w okolicach Łomży. Wokół Góry Zamkowej w Łomży narosło wiele opowiadań i legend. Władysław Świderski, żyjący w latach 1879-1942, prezydent Łomży od 1919 do 1934 roku, w publikacji Łomża z 14 ilustracjami i 3 planami miasta z XV, XIX i XX w., z 1925 r. poświęconej miastu Łomży, jego historii, opowieściom i podaniom z nim związanym, przytacza legendę właśnie o Górze Zamkowej, usytuowanej w okolicach Łomży. Według legendy Łomża była otoczona puszczą, do której nikt nie chodził, ponieważ bano się topielców, latawic i upiorów żądnych krwi ludzkiej. W miejscowości Szuru na górze znajdował się zamek, w którym mieszkał król z królową i młodą królewną. Po śmierci króla królowa przejęła panowanie. Była ona kobietą żądną władzy i bogactwa. Osoby w jej otoczeniu miały śniadą cerę, a w zamku działy się niecodzienne rzeczy. Dziewczęta z okolicznych wsi sprzątały na zamku. Zapłatę otrzymywały w formie śmieci, które zebrały. Po wyjściu z zamku miały się nie odwracać. Te, które dotrzymywały obietnicy, znajdowały w kieszeniach pieniądze zamiast śmieci, natomiast te, które się odwróciły, zamiast pieniędzy miały w fartuchach węże i żaby. Po drugiej stronie Narwi, na wzgórzach, mieszkał brat królowej. W pewnym momencie postanowiła ona przejąć panowanie także nad jego włościami. Podstępem zwabiła go i odprawiła przywiązanego do konia. Oswobodził go dopiero mieszkaniec wsi

9 T. Lippoman, op. cit., s. 161.

10 Z. Gloger, Liszków, „Tygodnik Ilustrowany” 1876, nr 48, s. 345. Biorąc pod uwagę, że Góra Zamkowa występowała w różnych miejscowościach i wiązała się z aspektem fundacyjnym, ciekawe byłoby opracowanie studium poświęconego historii i znaczeniu Góry Zamkowej w świadomości kulturowej i społecznej na przestrzeni dziejów. 
Siemień, który jako wynagrodzenie otrzymał tytuł szlachecki i dobra ziemskie. Lud był oburzony działaniami królowej i się zbuntował. W efekcie władczyni postanowiła wyjechać w rodzinne strony. Córka sprzeciwiła się matce i pozostała w królestwie. Królowa przeklęła zamek, który zapadł się w głąb góry wraz z królewną i wszystkimi skarbami. Śladem po zamku miały być żelazne wrota na wierzchołku góry, przywalone wielkim głazem. Wielu rycerzy próbowało przesunąć głaz i wydobyć skarby z wnętrza góry. Nikomu to jednak się nie udawało. W końcu przybył rycerz, który w swoim życiu nikomu nie wyrządził krzywdy i nie był zachłanny. Udało się mu odsunąć głaz i otworzyć wrota. Wszedł do wnętrza góry i odnalazł królewnę. Wyniósł ją na zewnątrz, pocałował, a ona odzyskała przytomność. Następnie młodzieniec uświadomił sobie, że nie ma nic do zaoferowania młodej dziewczynie i opanowany żądzą bogactwa postanowił wrócić do wnętrza góry po skarby. Po wejściu do lochu góra zamknęła swe wrota, a rycerz został w niej uwięziony. Miejsce, na którym stał zamek, jeszcze bardziej zapadło się w głąb ziemi. Królewna natomiast, płacząc po ukochanym, zmieniła się w mgłę opalową, a w miejscu rozstania młodych, powstało źródło ${ }^{11}$. Świderski, opisując historię miasta Łomży, podkreślał, że wzgórze koło Starej Łomży zapisało się w świadomości kulturowej i społecznej mieszkańców jako Góra Królowej Bony ${ }^{12}$. Warto nadmienić, że przytoczona legenda ma wiele odniesień do symboliki biblijnej. Motyw nakazu oddalenia się z zamku i góry bez oglądania się za siebie wiąże się z historią Lota, jego żony i dzieci podczas wyjścia z Sodomy. Aniołowie zakazali im oglądania się za siebie podczas wyjścia z miasta. Żona Lota nie wytrzymała i obejrzała się, w związku z czym spotkała ją za to kara, zmieniła się w słup soli ${ }^{13}$. Dziewczęta $\mathrm{z}$ legendy, które nie spełniły nakazu, również spotykała kara - zamiast zapłaty znajdowały w kieszeniach węże i żaby. W symbolice biblijnej wspomniane gady i płazy związane są ze światem zła - wąż kusiciel utożsamiany był z szatanem ${ }^{14}$, a żaby wiązały się $\mathrm{z}$ drugą plagą egipską ${ }^{15}$. W legendzie użyto również motywu wejścia w głąb góry symbolizującego przełamanie światów i płaszczyzn.

W podaniach ludowych można znaleźć opowieści o Górze Zamkowej nawiązujące do postaci Królowej Bony. Jaśko, parobek i grajek, wracając w zimowy wieczór do domu i przechodząc koło Góry Zamkowej, spotkał Królową Bonę. W pierwszym momencie wystraszył się jej, myśląc, że to diabeł. Ona zaczęła z nim rozmawiać i poprosiła, by dla niej zagrał. Uczynił to. Bardzo jej się podobało. Powiedziała Jaśkowi, że gdyby kiedyś czegoś potrzebował, może do niej

11 W. Świderski, Łomża z 14 ilustracjami i 3 planami miasta z XV, XIX i XX wieku, Łomża 1925, s. XI-XV.

12 Ibidem, s. 2.

13 Biblia Tysiąclecia, Księga Rodzaju, Zniszczenie Sodomy i Gomory, Poznań-Warszawa 1980, s. 38.

14 Biblia Tysiąclecia, Księga Rodzaju, Upadek pierwszych ludzi, Poznań-Warszawa 1980, s. 26.

15 Biblia Tysiąclecia, Księga Wyjścia, Plagi egipskie, Poznań-Warszawa 1980, s. 76. 
przyjść. Jednym warunkiem było, że musi to uczynić przed północą. Bona zniknęła w czeluściach góry, ponieważ wybiła godzina dwunasta w nocy. Pewnego razu pilnując bydła na łące, Jaś skupił się na muzyce i zwierzęta się rozeszły. Zaczął je zaganiać, ale jednej jałówki nie mógł znaleźć. Udał się po pomoc do Królowej Bony, na Górę Zamkową. Bona zgodziła się na pomoc finansową. Jasio musiał iść po pieniądze w głąb góry i odliczyć odpowiednią sumę. Uczynił to. Po pewnym czasie udał się kolejny raz do Królowej Bony. Zakochał się w córce młynarza, niestety dziewczyna nie zwracała na niego uwagi. Poprosił Bonę o pomoc. Ta powiedziała mu, jak ma odprawić rytuał miłosny. Jaś uczynił dokładnie wszystko, co nakazała mu Królowa, i w efekcie córka młynarza obdarzyła go wielką miłością. Oświadczył się jej, ale rodzice wybranki go odprawili i wyśmiali, ponieważ nie miał grosza przy duszy. Myślał, że w końcu się zgodzą, ale nie zmieniali zdania. W związku z tym kolejny raz udał się po poradę na Górę Zamkową do Królowej Bony. Bona powiedziała, że oczywiście, chętnie mu pomoże. Jaś wyliczył, że potrzebuje czterysta talarów. Miał się po nie udać jak za pierwszym razem, do wnętrza góry i dokładnie odliczyć. Zabierając pieniądze, skusił się, by przymierzyć stojące niedaleko nowe buty. Włożył je i w związku z tym, że właśnie wybijała godzina dwunasta, wybiegł w nich z wnętrza góry, przed jej zamknięciem. Niestety za swoje łakomstwo poniósł karę, buty zmieniły się w smołę. Spaliły mu się obie nogi. Został kaleką i musiał żebrać, czołgając się od wsi do wsi, a jego ukochana umarła z żalu ${ }^{16}$. W legendzie tej mamy odwołanie do motywu wejścia w głąb góry, czyli momentu przejścia ze świata ziemskiego do pozaziemskiego, oraz do liczby dwanaście - o godzinie dwunastej w nocy wrota góry się zamykały. Liczba dwanaście symbolizuje pełnię, całość, dwunastu apostołów.

Jadwiga Chrząszczewska i Jadwiga Warnkówna w książce pt. $Z$ biegiem Wisty. Obrazki z kraju także wspominają o Górze Królowej Bony w okolicach Łomży. Podkreślają, że w pamięci kulturowej krąży wiele podań odnoszących się do tego wzniesienia. Pokrótce przytaczają wspomniane wyżej legendy. Zwracają uwagę na to, że Bona zapisała się negatywnie w pamięci kulturowej jako zła matka, siostra i kobieta ${ }^{17}$.

Jak można zauważyć, Góra Zamkowa, Góra Królowej Bony na historycznym Podlasiu i w okolicach Łomży — współcześnie miasto identyfikowane jest $\mathrm{z}$ regionem Podlasia - kojarzone były w świadomości kulturowej z miejscem okrytym tajemnicą, związanym z duchami i demonami. Bano się tam wybierać ze względu na krążące historie. Jednakże wszystkie te tradycyjne podania mówiły o dobru i złu, o tym, że trzeba być cnotliwym, dobrym, że nie można być zachłannym ani próżnym. Każda $\mathrm{z}$ tych historii zakończona jest morałem na temat etycznego zachowania. Co ciekawe, każde z omawianych podań nacecho-

16 W. Niewińska, Legendy: województw: białostockiego, tomżyńskiego, suwalskiego, Białystok 1995, s. 24-31.

17 J. Chrząszczewska, J. Warnkówna, Z biegiem Wisty. Obrazki z kraju, Warszawa 1901, s. $284-286$. 
wane jest symboliką ze sfery sacrum i ukazuje przejście ze świata ziemskiego do świata pozaziemskiego, czy to związanego z bóstwami, czy duchami. Ponadto niejednokrotnie można odnaleźć odwołania do wrót czy głębi góry, które także w świadomości kulturowej symbolizowały świat pozaziemski. Wiele symboli ma odniesienia do tradycji biblijnej. Jak podkreślał Eliade: „a) święte miejsce stanowi zerwanie w homogeniczności przestrzeni; b) zerwanie to symbolizuje »otwór« umożliwiający przejście z jednego regionu kosmicznego do drugiego"18. Omawiany Jaśko czy rycerze z przytoczonej legendy wchodzą do wnętrza góry, przechodzą z jednego świata do drugiego. Mamy tu opisany moment przejścia ze świata profanum do sacrum. Świat pozaziemski owiany tajemniczością z jednej strony przyciąga, $\mathrm{z}$ drugiej strony budzi strach, wkomponowany jest $\mathrm{w}$ świat profanum, który jest jego odzwierciedleniem. Przełamanie płaszczyzn symbolizuje motyw przejścia.

O Górze Zamkowej wspomina także Zygmunt Gloger w publikacji Dolinami rzek. Opis podróży wzdluż Niemna, Wisły i Bugu ${ }^{19}$, przytacza, że według podań ludowych

góra ta usypaną, była rękoma jeńców wojennych, że we wnętrzu swojem zawiera podziemia pełne skarbów, że podziemia te pełne łączyły niegdyś zamek Drohicki z klasztorem Franciszkanów, w którego lochach miały znajdować się tajemne drzwi żelazne do tego przejścia na zamek [...] $]^{20}$.

Jak można zauważyć, podania miejscowe kształtujące świadomość i pamięć kulturową mieszkańców m.in. terenów wschodniej Polski ukazują Górę Zamkową w Drohiczynie jako górę owianą tajemniczą przeszłością, związaną z demonami, skarbami i duchami. Niektórzy badacze, jak Zygmunt Gloger, przedstawiciele szlachty, chociażby Julian Borzym próbowali „odbaśniowić” owo miejsce, szukając bardziej racjonalnych argumentów ukazujących historię góry. Gloger prowadził badania etnograficzne i krajoznawcze również na Górze Zamkowej w Drohiczynie, podkreślał, że:

Góra po starożytnym zamku składa się z twardej, gliniastej opoki, osypującej się ciągle od strony Bugu, który ją u podnóża nurtem swoim podmywa i zniszczył już w znacznej części. W połowie jej wysokości od strony rzeki dostrzegliśmy duży otwór. Po spadzistej, a po deszczu nader trudnej do wyjścia pochyłości, dostaliśmy się do tego otworu, który wprowadził nas do ciekawej pieczary, wykutej w opoce. Pieczarę stanowił prosty, wązki na trzy kroki korytarz, długi na kroków kilkanaście. W obu jego bokach znajdowały się po dwie przeciwległe sobie nisze, czyli wgłębienia, co nadawało lochowi podobieństwo do wnętrza miniaturowego kościółka, z czterema kapliczkami. Pieczara ta wszakże

18 M. Eliade, Sacrum i profanum, s. 29.

19 Z. Gloger, Dolinami rzek. Opis podróży wzdluż Niemna, Wisły i Bugu, Warszawa 1903.

20 Ibidem, s. 110. 
w czasach dawnych, gdy na górze stał zamek (niewątpliwie drewniany) była najpewniej więzieniem, lub skarbcem, a nie świątynią. W każdym razie musiała być znacznie dłuższą, bo zaczynała się w części góry, już dziś nie istniejącej, ta zaś część pieczary, która obecnie pozostała, stanowiła tylko zakończenie, do którego woda z deszczów naniosła sporo ziemi zewnętrznej. Niszczenie góry od strony Bugu odbywa się powoli, bo opoka gliniasta, z której się góra składa, jest tak twarda, że na ścianach pieczary, znaleźliśmy nazwiska zwiedzających, zapisane tu przed laty dwudziestu. Jeżeli zważymy, że pomimo takiej oporności opoki, tak znaczna część góry, może połowa, podmytą i zniszczoną już została, a na pozostałym jej wierzchołku nie ma już miejsca na zamek, to musimy przyjść do przekonania, że tylko za bardzo dawnych czasów, zamek warowny mógł być na górze Drohickiej założony w tem miejscu ${ }^{21}$.

Z tych słów wynika, że pieczara w Górze Zamkowej była najprawdopodobniej skarbcem bądź aresztem umieszczonym pod zamkiem, a nie miejscem tajemnym, z którego wypływali nocą rycerze czy też w którym mieścił się skarb pilnowany przez tajemniczego ducha Królowej Bony i demony. Wypowiedź Glogera ukazuje nam racjonalizację myśli na przełomie wieków. Moment odejścia od tradycyjnych ludowych tłumaczeń, uznawanych za baśnie, moment przejścia $\mathrm{w}$ racjonalizm, rozumne tłumaczenie zjawisk. W związku z tym owo „użycie rozumu” i racjonalnych dowodów, pozwala na „odtajemniczenie” góry, jej „odbaśniowienie”. Proces racjonalizacji prowadzi do podporzadkowania groźnej, tajemniczej natury umysłowi ludzkiemu. Dzięki temu góra, postrzegana przez wieki jako miejsce styku sacrum i profanum, pewnego rodzaju axis mundi, staje się elementem krajobrazu, który można podporządkować badaniom — czy to geologicznym, czy to krajoznawczym. Człowiek przejmuje kontrolę nad nieznanym, budzącym do tej pory strach, elementem przyrody. Podobny sposób racjonalizacji widać w opisie Góry Zamkowej z okolic Drohiczyna w tekście poświęconym historii miasta napisanym przez Józefa Jaroszewicza już w połowie XIX w. Jaroszewicz tłumaczy:

Sama góra zamkowa, na której stała niegdyś warownia, znacznie już zmieniła swą dawną postać. Zamek zniszczyła ręka ludzka, górę zaś czas, a bardziej wody Bugu ciągle podmywając, do tyla uszczupliły, że jej wierzchołek, na którym przed kilkodziesięcią laty, uczniowie szkoły Drohickiej jeszcze w piłkę grać mogli, dziś tak wązką przedstawia płaszczyznę, że dla małej nawet budowli nie byłoby na niej miejsca. W górze tej od strony Bugu widzieć można loch w ziemi rznięty, do którego niegdyś musiało być wejście $\mathrm{z}$ wierzchu, które się z czasem oberwało ${ }^{22}$.

21 Ibidem.

22 J. Jarosiewicz, Drohiczyn. Opis historyczny, „Athenaeum: pismo zbiorowe poświęcone historji, filozofji, literaturze, sztukom itd.” 4, 1847, s. 38. Zachowano zapis oryginalny tekstu z błędami. 
Pomimo racjonalnego tłumaczenia świata legendy zawsze pozostaną żywe w świadomości kulturowej społeczeństw. Mogą być uznawane przez badaczy za bajki dla ludu, ale ich nośność, tajemniczość, przyciąga po dzień dzisiejszy. Dlatego też niejednokrotnie we współczesnych przewodnikach turystycznych po terenach wschodniej Polski czy na stronach internetowych poświęconym atrakcjom turystycznym owych regionów można odnaleźć odwołania do dawnych podań ludowych i legend ${ }^{23}$.

Ciekawym uzupełnieniem literackim powyższej analizy jest książka Haliny Micińskiej-Kenarowej Pod Góra Królowej Bony ${ }^{24}$ odnosząca się do wydarzeń z początku XX wieku, mających miejsce w Krzemieńcu na Wołyniu, w miejscowości ulokowanej pod Górą Królowej Bony. Krzemieniec i motyw góry Królowej Bony odegrał bardzo ważną rolę w twórczości Juliusza Słowackiego ${ }^{25}$, który chociażby w poemacie pt. Godzina myśli ukazuje górę w gloryfikujący sposób, mianowicie:

Tam stoi góra, Bony ochrzczona imieniem,

Większa nad inne - miastu panująca cieniem;

Stary - posępny zamek, który czołem trzyma,

Różne przybiera kształty — chmur łamany wirem;

I w dzień strzelnic błękitnych spogląda oczyma,

A w nocy jak korona kryta żalu kirem,

Często szczerby wiekowe przesuwa powoli,

$\mathrm{Na}$ srebrzystéj xiężyca wschodzącego twarzy $[\ldots]^{26}$.

Twórczość Juliusza Słowackiego nie będzie omawiana dokładniej w niniejszym artykule, ponieważ wykracza to poza przyjęte ramy czasowe. Bohaterką powieści Pod Góra Królowej Bony jest dziewczynka ${ }^{27}$, która przybyła wraz z rodzicami do owej miejscowości, najprawdopodobniej w latach 20. XX w. Książka ukazuje jej przeżycia i doświadczenia zdobywane każdego dnia, emocje, które nią targały, smutki i radości. Góra Królowej Bony jest motywem przewodnim pracy, jest symbolem stałości w zmieniającym się świecie. Góra z jednej strony budzi przerażenie w małej dziewczynce, $\mathrm{z}$ drugiej zaś przyciąga ją i mami. Czytamy:

Jedna góra wdeptywała jak półwysep w sam środek puszystych sadów i czerwieni dachów. Miała na głowie dziwną zębatą koronę i Matka

${ }^{23}$ Największe atrakcje turystyczne $w$ województwie podlaskim, Białystok 2010, oraz portal ciekawe Podlasie, http://www.ciekawepodlasie.pl/ [dostęp: 8.01.2016].

${ }^{24}$ H. Micińska-Kenarowa, Pod Górą Królowej Bony, Kraków 1965.

25 Juliusz Słowacki urodził się i wychował w Krzemieńcu, gdzie uczęszczał do liceum. Jego twórczość nie będzie omawiana w artykule, gdyż wykracza poza przyjęte ramy czasowe, jednakże warto nadmienić, że jeden z rysunków Słowackiego, który namalował on, będąc jeszcze dzieckiem, przedstawiał Górę Królowej Bony. Wystawa Juliusza Słowackiego Godzina myśli, (culture.pl, 2005/04/11), http://culture.pl/pl/artykul/wystawa-juliusza-slowackiego-godzina-mysli [dostęp: 8.01.2016].

${ }^{26}$ H. Biegeleisen, Dzieła Juliusza Słowackiego, t. I, Lwów 1894, s. 322-323.

27 Wydaje się, że można ją identyfikować z autorką publikacji. 
powiedziała, że to ruiny zamku królowej Bony. „Co to znaczy bona, mamo?” - „Bona znaczy dobra, ale to była zła królowa”. Jakże mogła być zła, a nazywać się dobra? Góra obrastała niespokojnymi domysłami, obiecywała i mamiła, aż stała się pragnieniem większym niż śmietnik pod murem kościelnym ${ }^{28}$.

Potężna, panująca nad miastem góra owiana tajemnicą przyciągała uwagę dziecka. Góra i historia królowej zapadły w umysł dziewczynki, która targana emocjami pragnęła dowiedzieć się jak najwięcej o historii Bony oraz o sobie samej poprzez zdobycie szczytu góry. Dziecko, dowiedziawszy się, że królowa różnie była oceniana, pragnęło, by okazało się, że Bona była jednak dobrą władczynią. Problem dobra i zła jest obecny w całej książce. Dziewczynka nie może zrozumieć, dlaczego Bóg rodzi strach, dlaczego ma się go bać, dlaczego jest wszędzie nawet „w dziurce od klucza”29. Stara się czynić dobrze, jednakże nie zawsze dobre pobudki owocują dobrymi uczynkami. Problem wyborów, czynów dobrych i złych, wiary i zrozumienia świata, ukazany został poprzez walkę wewnętrznych emocji dziecka. Dziewczynka chce wejść na górę, chce zrozumieć historię Bony. Pewnego dnia była z babcią u ciotki; by do niej dojść, musiały wspiąć się do połowy góry. Relacjonowała: „Góra Bona rosła w oczach, grubiała, potężniała, puchła, a szczerbata korona na szczycie, chyliła się powoli do tyłu, aż znikała z tła nieba" ${ }^{30}$. Dziecko postanowiło się wspiąć na szczyt góry do zamku, celem potwierdzenia, że królowa nie była złym człowiekiem, że jej winy zostały odpuszczone. W umyśle bohaterki najlepszym dowodem na odpuszczenie win było oddanie Bonie klejnotu, który otrzymała od ciotki. Czytamy:

Klejnot był na pewno godny królowej Bony i postanowiłam nieodwołanie tego dnia ją odwiedzić. Do zamku było stąd już tylko pół góry i w miarę wspinania się kamienistą ścieżką malały domki miasta w dole i wyłaniały się na niebie grube, szczerbate mury. $Z$ daleka były o wiele piękniejsze, z bliska groziły ogromnymi głazami i nie osłaniały niczego, nie budowały, nie dawały przykrycia, otaczały tylko krągły, pusty, zielony plac. Ale w samym pępku tego placu była studnia. Cień murów od zachodu już ją obejmował, a w czarnej, niegłębokiej jamie nie lśnił żaden diament i królowej nie było. Odpięłam serduszko z księżycowych kamyków i wrzuciłam na dno studni. Zabłysło i królowa wiedziała już na pewno, że winy jej są zmazane i nigdy nie będzie się snuła po pustym dziedzińcu zrozpaczona zjawa ${ }^{31}$.

Góra w świadomości dziecka zapisała się jako spokojna królowa, która górowała nad miastem, nie tracąc swojego opanowania nawet w sytuacjach

\footnotetext{
${ }^{28}$ H. Micińska-Kenarowa, op. cit., s. 20.

29 Ibidem, s. 16.

30 Ibidem, s. 21-22.

31 Ibidem, s. 23-24.
} 
kryzysowych i trudnych dla mieszkańców, jak na przykład pożar. Dziewczynka relacjonowała:

Pożar apteki i składu tytoniowego [...] Na ulicy było jaśniej niż w dzień, a z czarnej nocy dookoła, poza tłumkiem rozbieganych ludzi, obudziła się tylko Góra Bona, wywleczona z rozespanej ciemności bluzganiem ognia u swoich stóp. [...] Od wpatrywania się w ogień bolały oczy, ale nie mogłam ich zamknąć, bo nawet każde mrugnięcie pozbawiało śledzenia ciągłości płomiennego nieubłagania. Góra Bona przygasała i cofała się w noc, ludzi na ulicy ubywało $[\ldots]^{32}$.

Z upływem czasu góra stawała się w umyśle głównej bohaterki coraz bardziej oswojona. W zimie zjeżdżano po niej na sankach ${ }^{33}$, co powodowało kolejny etap w „odtajemniczeniu” i „odbaśniowieniu”. Dziecko wraz z rozwojem i szukaniem odpowiedzi na nurtujące je pytania, stawało się coraz bardziej świadome i oswojone z otaczającym je światem. Strach przed nieznanym stawał się mniej odczuwalny. Ostateczną próbą dla bohaterki był moment pierwszej komunii i pierwszej spowiedzi świętej, który budził w niej niepokój i strach przed potępieniem. Bała się, że nie wykona spowiedzi w należyty sposób, że zapomni o grzechu, że nie jest na tyle dobra, by móc przystąpić do pierwszej komunii świętej. Targana emocjami, rezygnuje z przystąpienia do komunii świętej i znajduje ukojenie w Górze Królowej Bony. Czytamy:

Komunia stała się nie do przyjęcia z nie wyznanym, najważniejszym grzechem na sumieniu i powrót przed ołtarz był niemożliwy. Zrobiło się mi niedobrze i z trudem pchnąwszy ogromne, okute drzwi kościoła, wybiegłam na wysoki taras, z którego widać było całe miasto, przesłonięte srebrem wiosennej ulewy. Przede mną siedziała majestatyczna, obła, znajoma, dobra Bona [...] Nad połamanymi dachami domów z ganeczkami i kolumienkami strzelały w niebo cebule cerkwi i leżał wielki, gontowy dach synagogi. Tam można się było modlić także, chodzić na śluby i nabożeństwa i nikt nikogo nie zmuszał do spowiadania się z grzechów! Czy są na świecie rzeczy, których nie ma? Czy też nie ma rzeczy, które są? Dlaczego leżą w sercu kamiennym cierpieniem i strachem, skoro są piękne, dobre, znajome i bliskie?

Stałam tak długa chwilę pod ścianą ogromnego kościoła — oddzielona od świata i od samej siebie rzęsistym deszczem pytań bez odpowiedzi. Po czym - oddając na pastwę ulewy wstążki, krepdeszczyny, riuszki i biele, a także strojną lokami głowę — ruszyłam wolno przed siebie pod najwyższą górę - do zamku, który nigdy nie był dla mnie ruiną ${ }^{34}$.

32 Ibidem, s. 72-74.

33 Ibidem, s. 99.

34 Ibidem, s. 118-119. 
Książka Haliny Micińskiej-Kenarowej ukazuje na przykładzie głównej bohaterki ścieżkę przemiany wewnętrznej. Począwszy od strachu przed nieznanym i swoimi słabościami, przez rozwój duchowy zmetaforyzowany także wspinaczką i zdobywaniem szczytu, kończąc na zdobyciu ukojenia i stabilizacji dzięki uświadomieniu sobie, kim się jest, i odnalezieniu oparcia w opanowanej, spokojnej, dobrej Górze Królowej Bony. W utworze osobistemu wewnętrznemu rozwojowi człowieka towarzyszy motyw wspinania się i „oswajania” niedostępnej, owianej tajemnicą góry, podporządkowywania nieujarzmionej natury przez człowieka. Bohaterka przez osobisty rozwój wewnętrzny, osiągnięcie stabilizacji, co ilustruje oswajanie góry Królowej Bony, dojrzewa duchowo i oswobadza się z ram zewnętrznych, religijnych, narzuconych form, doznaje pewnego rodzaju wyzwolenia, co skutkuje wyjściem poza narzucone wzorce i ograniczenia oraz swobodą myślenia.

Symbolika sakralna zaś mocno wiąże się z Grabarką ${ }^{35}$, położoną na Podlasiu koło miejscowości Siemiatycze. Grabarka obecnie jest jednym z głównych miejsc kultu kościoła prawosławnego w Polsce. Nazwa góry po raz pierwszy pojawiła się na mapie opracowanej w 1785 r. „Cudowna” historia Grabarki związana jest z historią, która wydarzyła się w XVIII w. W 1710 r. w lecie wybuchła zaraza cholery w Siemiatyczach. Jeden z parafian obrządku wschodniego miał objawienie we śnie. Zgodnie z widzeniem ludność mogła być uratowana w wyniku zrobienia dużego krzyża i odbycia pielgrzymki na górę w uroczysku Sumieńszczyzna. Parafianin opowiedział sen proboszczowi, księdzu Pawłowi Smoleńskiemu, dla którego sen był objawieniem bożym. Duchowny postanowił wykonać wszystko, co Bóg nakazał. Zaprowadził ludzi na wzgórze porośnięte sosnami. Ze wzgórza wypływał strumyk — zaczęto pić z niego wodę. Pielgrzymi przeżyli. Stwierdzono, że mieszkańcy pogrążonego w chorobie miasta zostali uratowani, gdyż odbyli pielgrzymkę oraz napili się wody ze źródła. Uznano to za cud. Wieść rozeszła się do innych miejscowości i ludzie pielgrzymowali do źródła na wzgórzu. Epidemia ustała. W celu dziękczynnym postanowiono wybudować na szczycie cerkiew ${ }^{36}$. Budowa sanktuarium uświęcała miejsce, jak podkreśla Eliade: „Dzięki świątyni świat zostaje na nowo uświęcony w całej swojej całkowitości”37. W XIX w. w wyniku likwidacji kościoła unickiego i przejęcia go przez kościół prawosławny, cerkiew na górze podporządkowano temu rytowi. Rodziło to niejednokrotnie konflikty, jednakże w efekcie góra i sanktuarium stały się terenem kultu prawosławnego ${ }^{38}$. Jak podkreśla Maria Giedz: „Wraz z likwidacją Unii, w drugiej połowie XIX w., po przejęciu Grabarki przez kościół prawosławny, zaczęto budować sztuczną tradycję, która nie ma potwierdzeń w źródłach archiwalnych"39. Według nowo stworzonej tradycji w wieku XII bądź na początku XIII mieszkańcy

35 Informacje na temat Świętej Góry Grabarki opierają się głównie na źródłach wtórnych, ze względu na fakt, że autorce artykułu nie udostępniono źródeł archiwalnych.

36 M. Giedz, Grabarka. Sanktuarium kościoła prawosławnego, Warszawa 1987, s. 1-3.

37 M. Eliade, Sacrum i profanum, s. 48.

38 M. Giedz, op. cit., s. 1-3.

39 Ibidem, s. 3. 
Mielnika wyłowili z Bugu obraz Przemienienia Pańskiego (Spasa Izbawiennika). Obraz miadał cudowne uzdrawiające moce, dlatego też ludność postanowiła wybudować cerkiew, do której pielgrzymowano. W latach 40. XIII w. mieszkańcy wraz z cudownym obrazem schronili się w Puszczy Mielnickiej przed Tatarami. Obraz umieszczono w kaplicy wybudowanej na górze. W kolejnych wiekach kult ikony osłabł. Sytuację tę w następujący sposób komentuje Maria Giedz:

Tradycja ludowa głosi o ciągłym przebywaniu cudownej ikony (Spasa) nad Bugiem. Podanie mówi o powstaniu sanktuariów Spasa Izbawiennika na górkach w lasach nadbużańskich. Jednym z nich miała być Moszczona Pańska, w której do I wojny światowej znajdowały się pustelnie i mnisi czczący nieznaną bliżej ikonę Zbawiciela. Zapewne Grabarka mogła być jednym z miejsc przebywania tej ikony lub ośrodkiem jej kultu, zwłaszcza, że na terenie sanktuarium chowano ofiary epidemii i najazdów. Według S. Stolarczyka nazwa Grabarki pochodzi od białoruskiego słowa - hrabar - kopacz, człowiek kopiący groby, rowy. [...] Z wywiadów z ludnością prawosławną wynika, że ta nie poparta źródłami historycznymi legenda istniała już w 2 połowie XIX w. Całe to legendarium stanowiło jeden z elementów ideologii narzuconego odgórnie przez carat urzędowego prawosławia. Świadczy o tym miedzy innymi fakt, że część ludności prawosławnej obecnie pozostaje przy starej legendzie unickiej rozpoczynającej historię Grabarki dopiero od zarazy w $1710 \mathrm{r}^{40}$

W końcu XIX w. kaplica na górze została rozbudowana, po I wojnie światowej nadal odprawiano w niej nabożeństwa i funkcjonował przy niej cmentarz. Po II wojnie światowej, w 1947 r. założono żeński klasztor prawosławny na Górze Grabarce. Pierwszą przełożoną klasztoru została Maria Komstadius. Następnie zaczęto rozwijać zabudowę klasztorną i okołoklasztorną. W 1953 r. zaczęto budować nowy dom mieszkalny, którego połowa została przeznaczona na zimową część cerkiewną. Szóstego listopada 1956 r. poświęcono cerkiew powołania Matki Boskiej Wspomożycielki i Opiekunki. Dzień ten jest dniem odpustowym na Grabarce ${ }^{41}$.

Na szczycie góry znajduje się cerkiew. Jest to drewniany budynek z wieżą:

w przyziemiu, której znajduje się przedsionek (babiniec — pritwor), z dwudzielną nawą (część środkowa) zamkniętą od wschodu prostokątnym prezbiterium (altar). Bryła cerkwi pokryta jest wspólnym, dwuspadowym dachem o jednej kalenicy, krytym gontem. Na dachu nad partią nawy znajduje się wieżyczka na sygnaturkę. Cerkiew z trzech stron (północnej, wschodniej i południowej) otoczona jest rzędami drewnia-

40 Ibidem, s. 4. Tradycja ta została opisana w następujących publikacjach: D. Sawicki, Grabarka. Monaster na Świętej Górze 1947-2007, Białystok 2007; A. Radziukiewicz, Święta Góra Grabarka, Białystok 1995; A. Radziukiewicz, Grabarka. Góra krzyży i modlitwy, Białystok 2001.

${ }^{41}$ M. Giedz, op. cit., s. 4-5. 
nych, kamiennych i metalowych krzyży wotywnych różnej wielkości, wykonanych w 2. połowie XIX w. i w XX w. [... $]^{42}$

Na części krzyży, na dłuższym ramieniu, zostały wyryte intencje wotywne, na niektórych w dolnej części w oszklonej wnęce znajdują się zdjęcia, święte obrazki bądź papierki z prośbami. Wiele z krzyży przewiązano wstążkami symbolizującymi perizonium bądź odnoszącymi się do prawosławnej tradycji przewiązywania Jezusa na krzyżu przez Marię kolorową tkaniną. Krzyże dekorowano także suszonymi kwiatami bądź wiązankami z szyszkami. Rzadkością są krzyże z przywiązanym płótnem z wyciętymi wzorami, nawiązującymi do pogańskiej tradycji opłaty Bogu za zmarłą duszę. Na wschód za cerkwią znajduje się cmentarz. Na południowej stronie wzgórza, w starszej części cmentarza, znajdują się krzyże dekorowane wstążkami i plastykowymi bukietami ${ }^{43}$.

W świadomości kulturowej i religijnej Grabarka postrzegana jest jako Święta Góra. W pamięci kulturowej zapisało się wiele legend i opowieści o cudach, które miały na niej miejsce. Oprócz cudu z roku 1710 mówi się o następującym, który wydarzył się jeszcze przed erygowaniem monasteru:

Okresu sprzed erygowania monasteru dotyczy cud, o którym opowiedział jeden z mieszkańców wsi Grabarka. Pewnego razu ujrzał on kobietę i mężczyznę, którzy klęcząc modlili się, zwróceni w kierunku cerkwi. Rozpoczął rozmowę. Dowiedział się, że mężczyzna jeszcze niedawno bardzo ciężko chorował. Całe jego ciało pokryło się bolącymi i swędzącymi strupami. Żadne lekarstwo nie zdołało złagodzić jego cierpień. Zdesperowany udał się do swojego proboszcza, ojca Kudriawcewa z Kleszczel. Ten modlił się nad nim, a później dał mu wodę ze źródełka (najprawdopodobniej grabarskiego). Polecił również pojechać na Grabarkę i tam modlić się o uzdrowienie. Mężczyzna z nadzieją i wiarą wypełnił radę duchownego. Już w czasie drogi zauważył, że strupy stopniowo znikają. U podnóża Świętej Góry praktycznie już ich nie było. Uzdrowiony ze łzami w oczach poszedł do świątyni Przemienienia Pańskiego, podziękować Bogu za łaskę ${ }^{44}$.

Jak można zauważyć, Góra Grabarka związana jest w świadomości kulturowej z miejscem świętym, cudownym, które dzięki łasce boga uśmierza cierpienie. Będąc tam, człowiek łączy się ze światem sacrum i dostępuje jego łaski. W ostatnich czasach Grabarkę zaczęto łączyć z miejscem magicznym - z miejscem mocy. „Mistrzowie ezoteryki uważają, że strumień energii, który płynie z Wielkiej Pi-

\footnotetext{
42 Ibidem, s. 1.

43 Ibidem.

44 D. Sawicki, op. cit., s. 19.
} 
ramidy w egipskiej miejscowości Giza pod Kairem, dociera... aż do Grabarki. Potwierdza to znawca naturalnego promieniowania Ziemi Leszek Matela”45.

Góry w regionach wschodniej Polski w okresie przełomu XIX i XX w. identyfikowano ze światem sacrum bądź wiązano je ze światem demonów i duchów. Podania ludowe, legendy dotyczące czy to Góry Zamkowej, czy to Góry Królowej Bony, niejednokrotnie nacechowane były odwołaniami do świata duchów i demonów, do walki dobra ze złem. Góra Grabarka zaś wiązana była w świadomości i pamięci kulturowej tylko i wyłącznie ze sferą religijna i sakralną, a moc jej przypisana i podania o cudach wzmacniały tę identyfikację, czego wyrazem była i jest liczba krzyży wotywnych na jej szczycie i związany z nią ruch pielgrzymkowy. Na przełomie wieków zaczęto podejmować próby racjonalnego wytłumaczenia historii poszczególnych gór, co czynił chociażby Zygmunt Gloger, choć w świadomości społecznej tradycyjne legendy z pewnością odgrywały nadal dużą rolę. Motyw gór był także popularny w literaturze pięknej. Literacka opowieść Haliny Micińskiej-Kenarowej przedstawiająca zmagnia z własnymi słabościami oraz rozwój duchowy w metaforycznym odwołaniu do zdobywania szczytu góry ilustruje zmniejszenie dystansu człowieka do natury i „odbaśniowienie”, „odtajemniczenie” pewnych elementów przyrody. Góra zapisała się w świadomości kulturowej na wschodzie Polski na przełomie wieków XIX i XX jako symbol świata pozaziemskiego, miejsce kontaktu ze sferą demonów, bogów, duchów, miejsce święte a zarazem element natury, który można było sobie podporządkować.

\section{The Castle Mount, Queen Bona Mount and Mount Grabarka — the symbolism of "lesser known mountains" in the culture of the eastern regions of Poland at the turn of the 20th century}

\section{Summary}

The aim of the article is to examine the significance of "lesser known mountains", namely Castle Mount, Queen Bona Mount and Mount Grabarka in the cultural consciousness of people living in eastern Poland at the turn of the 20th century (Podlasie and Volhynia). In folk tales the symbolism of the mountains was associated with the extraterrestrial world. Mountains aroused fear; they were regarded as the abodes of evil spirits and places where souls of sinners did their penance and wandered. With time the symbolism of the mountains among people living in eastern Poland began to change. At the turn of the century attempts were made to rationalise the perception of nature as well as to tame it and subordinate it to humans. Examples of such an approach include Zygmunt Gloger's ethnographic descriptions of e.g. Castle Mount near Drohiczyn. Queen Bona Mount was to be found in Podlasie and Volhynia. A literary illustration by Halina Micińska-Kenar, entitled Pod górą królowej Bony [At the Foot of Queen

45 https://hipokrates2012.wordpress.com/2013/01/10/miejsca-magiczne-grabarka/ [dostęp: 18.09.2015]. 
Bona Mount], explores fear of the unknown - a mountain dominating the town - as well as the path of humans' spiritual development through overcoming their weaknesses and ascending the peak. Often mountains were also associated with divine locations. An example is Mount Grabarka (Podlasie), from which flows a holy spring, symbolising a holy place and a place of remembrance. An analysis of the symbolism of the mountains in Poland's eastern region shows what places were and are regarded as mountains as well as why and what significance was attributed to these "smaller mountains" in the cultural consciousness of people living in these regions at the turn of the 20 th century.

Keywords: mount, memoirs, Borderlands, cultural frontier 